\title{
Energetic metabolism, milk production, and inflammatory response of transition dairy cows fed rumen-protected glucose
}

\author{
C. S. McCarthy, ${ }^{1}$ B. C. Dooley, ${ }^{1}$ E. H. Branstad, ${ }^{1}$ A. J. Kramer, ${ }^{1}$ E. A. Horst, ${ }^{1}$ E. J. Mayorga, ${ }^{1}$ M. Al-Qaisi, ${ }^{1}$ \\ M. A. Abeyta, ${ }^{1}$ G. Perez-Hernandez, ${ }^{2}$ B. M. Goetz, ${ }^{1}$ A. R. Castillo, ${ }^{3}$ M. R. Knobbe, ${ }^{4}$ C. A. Macgregor, ${ }^{4}$ \\ J. P. Russi, ${ }^{5}$ J. A. D. R. N. Appuhamy, ${ }^{1}$ H. A. Ramirez-Ramirez, ${ }^{1}$ and L. H. Baumgard ${ }^{1 *}$ \\ ${ }^{1}$ Department of Animal Science, lowa State University, Ames 50011 \\ ${ }^{2}$ Universidad Autónoma Chapingo, General Villegas, Chapingo, México \\ ${ }^{3}$ University of California, Cooperative Extension, Merced 95340 \\ ${ }^{4}$ Grain States Soya Inc., West Point, NE 68788 \\ ${ }^{5}$ Rusitec Argentina, General Villegas, Buenos Aires 6230, Argentina
}

\begin{abstract}
Objectives were to evaluate the effects of rumen-protected glucose (RPG) supplementation on milk production, post-absorptive metabolism, and inflammatory biomarkers in transition dairy cows. Fifty-two multiparous cows were blocked by previous 305-d matureequivalent milk (305ME) yield and randomly assigned to 1 of 2 iso-energetic and iso-nitrogenous treatments: (1) control diet (CON; $n=26)$ or (2) a diet containing RPG (pre-fresh $5.3 \%$ of dry matter and $6.0 \%$ of dry matter postpartum; $\mathrm{n}=26$ ). Cows received their respective dietary treatments from $\mathrm{d}-21$ to 28 relative to calving, and dry matter intake was calculated daily during the same period. Weekly body weight, milk composition, and fecal $\mathrm{pH}$ were recorded until $28 \mathrm{~d}$ in milk (DIM), and milk yield was recorded through 105 DIM. Blood samples were collected on $\mathrm{d}-7,3,7,14$, and 28 relative to calving. Data were analyzed using repeated measures in the MIXED procedure (SAS Institute Inc., Cary, NC) with previous $305 \mathrm{ME}$ as a covariate. Fecal $\mathrm{pH}$ was similar between treatments and decreased (0.6 units) postpartum. Dry matter intake pre- and postpartum were unaffected by treatment, as was milk yield during the first 28 or 105 DIM. Milk fat, protein, and lactose concentration were similar for both treatments. Blood urea nitrogen and plasma glucose concentrations were unaffected by treatment; however, results showed increased concentration of circulating insulin (27\%), lower nonesterified fatty acids $(28 \%)$, and lower postpartum $\beta$-hydroxybutyrate $(24 \%)$ in RPG-fed cows. Overall, circulating lipopolysaccharide-binding protein and haptoglobin did not differ by treatment, but at 7 DIM, RPG-fed cows had decreased lipopolysaccha-
\end{abstract}

Received January 3, 2020

Accepted March 5, 2020.

*Corresponding author: baumgard@iastate.edu ride-binding protein and haptoglobin concentrations (31 and 27\%, respectively) compared with controls. Supplemental RPG improved some biomarkers of postabsorptive energetics and inflammation during the periparturient period, changes primarily characterized by increased insulin and decreased nonesterified fatty acids concentrations, with a concomitant reduction in acute phase proteins without changing milk production and composition.

Key words: rumen glucose, ketosis, transition period

\section{INTRODUCTION}

Glucose is the precursor for lactose synthesis, with lactose being the primary osmoregulator of milk synthesis (Neville et al., 1983; Cant et al., 2002). During established lactation, hepatic glucose output precisely meets peripheral tissue (i.e., mammary, muscle, adipose, central nervous system) glucose requirements, and thus, circulating glucose is homeostatically maintained within a narrow range (Baumgard et al., 2017). The mammary gland requires approximately $72 \mathrm{~g}$ of glucose to produce $1 \mathrm{~kg}$ of milk (Kronfeld, 1982), and the homeorhetic control during established lactation indicates that milk synthesis is not limited by glucose supply (Amaral-Phillips et al., 1993; Bell and Bauman, 1997; Lemosquet et al., 2009). However, glucose availability has been hypothesized to limit milk yield in specific circumstances, including the periparturient period (Overton and Waldron, 2004), immunoactivation (Kvidera et al., 2017), and heat stress (Baumgard and Rhoads, 2013).

During the transition period, energy output (accounted for by milk synthesis and maintenance costs) exceeds dietary energy intake, resulting in cows entering into calculated negative energy balance (NEBAL). This energetic deficit is of particular importance because NEBAL presumably makes cows more sus- 
ceptible to metabolic disorders such as ketosis, fatty liver, and displaced abomasum, and increases risks of mastitis and infertility (Drackley, 1999). With regards to bioenergetics, inadequate feed intake during the periparturient period means that diet-derived gluconeogenic precursors contribution to hepatic glucose output is insufficient to meet the mammary gland's increasing requirement (Bell, 1995). Consequently, multiple tissues coordinate efforts in an attempt to compensate for the dietary shortage (propionate and amino acids) by becoming insulin resistant and catabolic via mobilization of amino acids and glycerol, from skeletal muscle and adipose tissue, respectively (Bell, 1995; Bell and Bauman, 1997). In addition, reduced insulin activity in adipose tissue allows for increased lipolysis, and the resulting nonesterified fatty acids (NEFA) are directly oxidized by capable tissues and contribute to wholebody energetics by hepatic interconversion of partially oxidized NEFA into ketone bodies (Bauman and Currie, 1980). Further, skeletal muscle and adipose tissue insulin resistance "spares glucose" for mammary utilization (Baumgard et al., 2017). These glucose-sparing and metabolic adaptations are employed in an effort to maximize milk production, due to the temporal discrepancy between the increase in energy requirements of the mammary gland and dietary energy supply.

In addition to galactopoiesis, mounting an immune response is quantitatively a glucose-intensive process (Waldron et al., 2006; Kvidera et al., 2017). Practically all transition dairy cows experience some degree of inflammation, regardless of their overt clinical health status (Humblet et al., 2006). The inflammation origin is not always clear; however, probable sources during the transition period are the uterus and mammary gland (Bradford et al., 2015), as well as the gastrointestinal tract (Khafipour et al., 2009; Abuajamieh et al., 2016). Hence, glucose availability is critically important to promote both maximal milk synthesis and immunity, which is especially relevant during the transition period. However, optimizing the post-absorptive "carbohydrate status" in ruminants is difficult, because adding more dietary soluble carbohydrates by increasing the starch, sugar, and soluble fiber may compromise rumen function and health (Aschenbach et al., 2011). Therefore, providing a dietary source of glucose that is minimally fermented in the rumen, but readily available in the small intestine, may offer a safe nutritional strategy to increase intestinal glucose supply, thus improving milk production and supporting postpartum immune function. We hypothesized that early-lactation whole-body glucose production (hepatic, intestinal, and kidney) output and glucose-sparing mechanisms may be insufficient to sustain peripartum inflammation and optimum milk yield in dairy cows. Therefore, our objectives were to determine if feeding a source of rumen-protected glucose (RPG) throughout the transition period would alter bioenergetic metabolism, increase milk production, and influence immune biomarkers.

\section{MATERIALS AND METHODS}

\section{Animals, Experimental Design, and Diets}

All procedures were approved by the Iowa State University Institutional Animal Care and Use Committee. Multiparous Holstein cows $(\mathrm{n}=52)$ were used in a randomized block design based on their previous 305d mature-equivalent milk yield (305ME) to test the effects of supplemental RPG. Dietary treatments were either a control diet $(\mathrm{CON} ; \mathrm{n}=26)$ or a diet containing RPG (pre-fresh $5.3 \%$ of DM and $6.0 \%$ of DM postpartum; $n=26$ ). Glucose is presumed to be ruminally protected, based on the Maillard reaction. Following the chemical reaction, the resulting sugar-amino complex is minimally affected by ruminal fermentation (Van Soest, 1994; Kostyukovsky and Marounek, 1995). The feed supplement used in this study was a proprietary mixture of soybean meal and glucose subjected to a controlled Maillard reaction, as previously described (United States Patent 8,507,025. Rupca LLC, Merced, CA). This particular supplement is $50 \%$ protected from ruminal metabolism (United States Patent 8,507,025).

Treatments began $21 \pm 5 \mathrm{~d}$ before expected parturition date and continued until 28 DIM. Immediately postpartum, cows were milked and processed according to standard operating procedures implemented at the farm. Pre- and post-parturition, cows were individually fed $110 \%$ of their ad libitum consumption using the Calan Broadbent feeding system (American Calan, Northwood, NH). Feed was delivered once daily and orts were recorded before feeding to adjust feed allowance. Diets were balanced to be iso-nitrogenous and iso-energetic and formulated to meet predicted requirements of energy, protein, minerals, and vitamins for each stage of production (NRC, 2001; Table 1). Cows were milked thrice daily at 0700,1500 , and $2300 \mathrm{~h}$, and yield was automatically recorded at each milking.

\section{Sampling and Data Collection}

Feed Sampling. Total mixed ration samples were collected weekly on 2 consecutive days, composited to obtain 1 sample per week, and stored at $-20^{\circ} \mathrm{C}$ until trial completion. The TMR samples were dried in a forced-air oven at $60^{\circ} \mathrm{C}$ for $48 \mathrm{~h}$ to determine $\mathrm{DM}$ content. Diet composition was analyzed by an external laboratory (Cumberland Valley Analytical Services, Waynesboro, PA) and included DM (method 930.15; 
AOAC International, 2000), nitrogen (method 990.03; Leco FP-528 Nitrogen Combustion Analyzer, Leco Corp., St. Joseph, MI), NDF (Van Soest et al., 1991), starch (Hall, 2009), ether extract using diethyl ether as the solvent (method 2003.05; AOAC International, 2006), and ash (method 942.05; AOAC International, 2000). Lignin was determined as described by Goering and Van Soest (1970) with the following modification: fiber residue from the ADF step was recovered on a $1.5-\mu \mathrm{m}$ particle-retention filter $(7 \mathrm{~cm}$ Whatman glass fiber filter, Cytiva, Marlborough, MA). Subsequently, the fiber residue and filter were transferred to a capped tube and approximately $45 \mathrm{~mL}$ of $72 \%$ sulfuric acid were added. Tubes were gently agitated for $2 \mathrm{~h}$ to ensure that all fiber material was continually washed with acid. The contents of the tube after incubation in acid was filtered onto a second filter which was then rinsed, dried, and weighed. The glass fiber filters and lignin residue were ashed for $2 \mathrm{~h}$ in a furnace to remove lignin organic matter. Finally, the filter and ash residue were weighed and subtracted from the original weight to determine grams of lignin. Minerals were determined per AOAC International (2000) with modifications that included ashing $0.35 \mathrm{~g}$ sample for $1 \mathrm{~h}$ at $535^{\circ} \mathrm{C}$ followed by digestion in open crucibles for $20 \mathrm{~min}$ in $15 \%$ nitric acid on a hotplate. Samples were then diluted to $50 \mathrm{~mL}$

Table 1. Ingredient and chemical composition of pre-fresh and lactating diets (average \pm SD in parentheses)

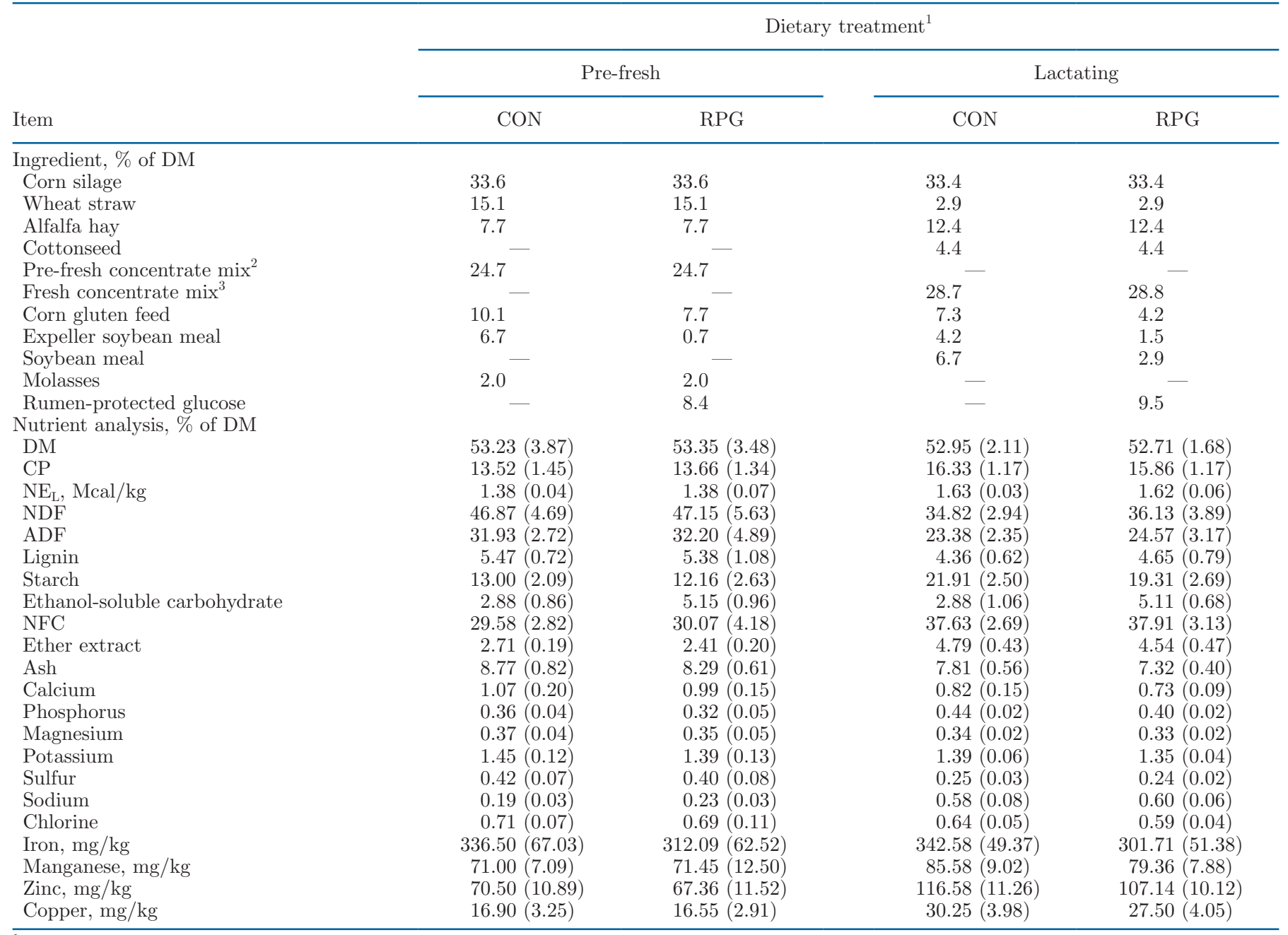

${ }^{1} \mathrm{CON}=$ control; RPG $=$ rumen-protected glucose diet.

${ }^{2}$ Pre-fresh concentrate composition (DM basis) = ground corn $24.7 \%$, soybean hulls $18.5 \%$, wheat midds $17.8 \%$, anionic salts $14.1 \%$, calcium carbonate $7.8 \%$, soybean meal $4.6 \%$, rumen-protected choline $1.6 \%$, calcium sulfate $1.7 \%$, magnesium sulfate $1.7 \%$, choice white grease $0.9 \%$, monocalcium phosphate $0.8 \%$, sodium chloride $0.9 \%$, liquid methionine hydroxy analogue $0.7 \%$, yeast product $0.5 \%$, magnesium oxide $0.5 \%$, additives, vitamin and mineral premix $3.2 \%$.

${ }^{3}$ Fresh concentrate composition (DM basis) = ground corn $72.3 \%$, dried distillers grains with solubles $6.8 \%$, pork bone and meat meal $3.7 \%$, calcium carbonate $3.6 \%$, sodium bicarbonate $2.8 \%$, blood meal $2.3 \%$, rumen inert fat $2.6 \%$, sodium chloride $1.4 \%$, rumen-protected lysine $1.0 \%$, rumen-protected methionine $0.3 \%$, liquid methionine hydroxy analogue $0.2 \%$, yeast product $0.2 \%$, additives, vitamin and mineral premix $2.8 \%$. 
and analyzed by inductively coupled plasma (method 985.01; AOAC International, 2000).

Milk Production. Daily milk yield was condensed into weekly averages through 105 DIM. Milk composition was determined for individual milk samples obtained at each of 6 consecutive milkings on 2 consecutive days per week for the first 4 wk of lactation. Samples were stored at $4^{\circ} \mathrm{C}$ with a bronopol pellet as preservative (D \& F Control Systems, San Ramon, CA) until analyzed by an external laboratory (Dairy Lab Services, Dubuque, IA) using AOAC-approved analysis equipment and procedures (AOAC International, 1995). Milk samples were analyzed for milk fat, protein, lactose, and MUN, using Fourier transform infrared spectroscopy (MilkoScan FT+, FOSS Analytical, Eden Prairie, MN). Yield of protein, fat, and lactose were estimated using the corresponding milk yields for each sampling.

Blood Metabolites, Hormones, and Acute Phase Proteins. Blood samples were obtained via coccygeal venipuncture once $(1400 \mathrm{~h})$ on $\mathrm{d}-14( \pm 4$ d) and $-7( \pm 4 \mathrm{~d})$ relative to expected parturition, and on d $3,7,14,21$, and 28 relative to actual parturition date. All samples were collected into $10-\mathrm{mL}$ vacuum collection tubes $\left(\mathrm{K}_{2}\right.$ EDTA; BD Franklin Lakes, NJ). Plasma samples were harvested following centrifugation at $1,500 \times g$ for $15 \mathrm{~min}$ at $4^{\circ} \mathrm{C}$ and were subsequently frozen at $-20^{\circ} \mathrm{C}$ until analyzed. Plasma samples from a subset of cows (CON, $\mathrm{n}=13$; $\mathrm{RPG}, \mathrm{n}=13$ ) were randomly selected for retrospective blood analysis of NEFA, BHB, BUN, and glucose. This data set included samples obtained on $\mathrm{d}-14,-7,3,7,14$, and $28 \pm 1$ relative to parturition. Samples from the same subset of cows collected on $\mathrm{d}-7 \pm 1$, and 7,14 , and 28 relative to parturition, were analyzed for lipopolysaccharidebinding protein (LBP), haptoglobin $(\mathbf{H p})$, and insulin. Plasma insulin, NEFA, BHB, LBP, Hp, BUN, and glucose concentrations were determined using commercially available kits according to manufacturers' instructions (insulin, Mercodia AB, Uppsala, Sweden; NEFA, Wako Chemicals USA, Richmond, VA; BHB, Pointe Scientific Inc., Canton, MI; LBP, Hycult Biotech, Uden, the Netherlands; Hp: Immunology Consultants Laboratory Inc., Portland, OR; BUN, Teco Diagnostics Anaheim, CA; glucose, Wako Chemicals USA Inc., Richmond, VA).

Animal Measurements. Body weight and BCS were determined twice weekly on consecutive days throughout the experimental period and condensed into weekly averages. The BCS were measured by 2 trained individuals utilizing Wildman et al. (1982) scoring system but reported in 0.25-unit increments.

Fecal $p \boldsymbol{H}$. Fecal samples ( $200 \mathrm{~g}$ wet basis) were collected weekly from $\mathrm{d}-21$ to 28 relative to parturition, upon spontaneous defecation or via rectal palpation. Samples were allowed to equilibrate to room temperature, and $\mathrm{pH}$ was determined according to the method described by Branstad et al. (2017). Briefly, a subsample of $25 \mathrm{~g}$ was used in a 1:1 dilution with distilled water and homogenized for $1 \mathrm{~min}$ in a blender (Stomacher 80, Seward Ltd., West Sussex, UK). The homogenate was strained through 1 layer of cheesecloth, and fecal $\mathrm{pH}$ was then measured on the liquid, using a portable pH meter (Oakton Instruments, Vernon Hills, IL). The remaining intact fecal sample was stored at $-20^{\circ} \mathrm{C}$.

\section{Statistical Analysis}

Data were analyzed as a completely randomized design with repeated measures using the MIXED procedure (SAS Institute Inc., Cary, NC). Fixed effects included treatment, time, and the interaction of treatment and time. Cow was included as a random effect. Each cow's previous 305ME served as a covariate. The Akaike information criterion was used to select the most appropriate covariance structure. Autoregressive 1 structure was used to analyze BW, milk yield, milk components, ECM, 3.5\% FCM, and feed efficiency. Spatial power structure was used to analyze DMI and plasma metabolites, hormones, and acute phase proteins. Data were reported as LSM and considered significant if $P \leq 0.05$ and a tendency if $0.05<P \leq 0.10$.

\section{RESULTS}

\section{$D M I$, Fecal $p H$, and BW}

The dietary formulations presented in Table 1 were intended to be iso-nitrogenous and iso-energetic. Specifically, prepartum CON and RPG diets contained 29.58 and $30.07 \%$ NFC, respectively, with an estimated 1.38 Mcal of $\mathrm{NE}_{\mathrm{L}} / \mathrm{kg}$ of DM for both diets. Similarly, the NFC content of the lactating diets was 37.63 and $37.91 \%$ for CON and RPG diets with $1.63 \mathrm{Mcal}$ of $\mathrm{NE}_{\mathrm{L}} /$ $\mathrm{kg}$ of $\mathrm{DM}$ for both. The $\mathrm{NE}_{\mathrm{L}}$ for the pre-fresh CON and RPG TMR was calculated from actual laboratory analysis and was $97.1 \%$ of the targeted formulated value. The analyzed $\mathrm{CP}$ for the pre-fresh $\mathrm{CON}$ and $\mathrm{RPG}$ TMR were 100.1 and $99.7 \%$ of the formulated values, respectively. Similarly, the $\mathrm{NE}_{\mathrm{L}}$ values for the lactating CON and RPG TMR were $101.2 \%$ of the formulated diets, and the analyzed CP for the lactating CON and RPG TMR were 100.2 and $99.7 \%$ of the formulated CP content, respectively.

Body weight $(757 \pm 17 \mathrm{~kg} ; P>0.16)$ and BCS (3.31 $\pm 0.05 ; P>0.41)$ were similar between treatments and affected similarly by time (data not shown). Overall DMI was similar between treatments $(P>0.64$; Figure 

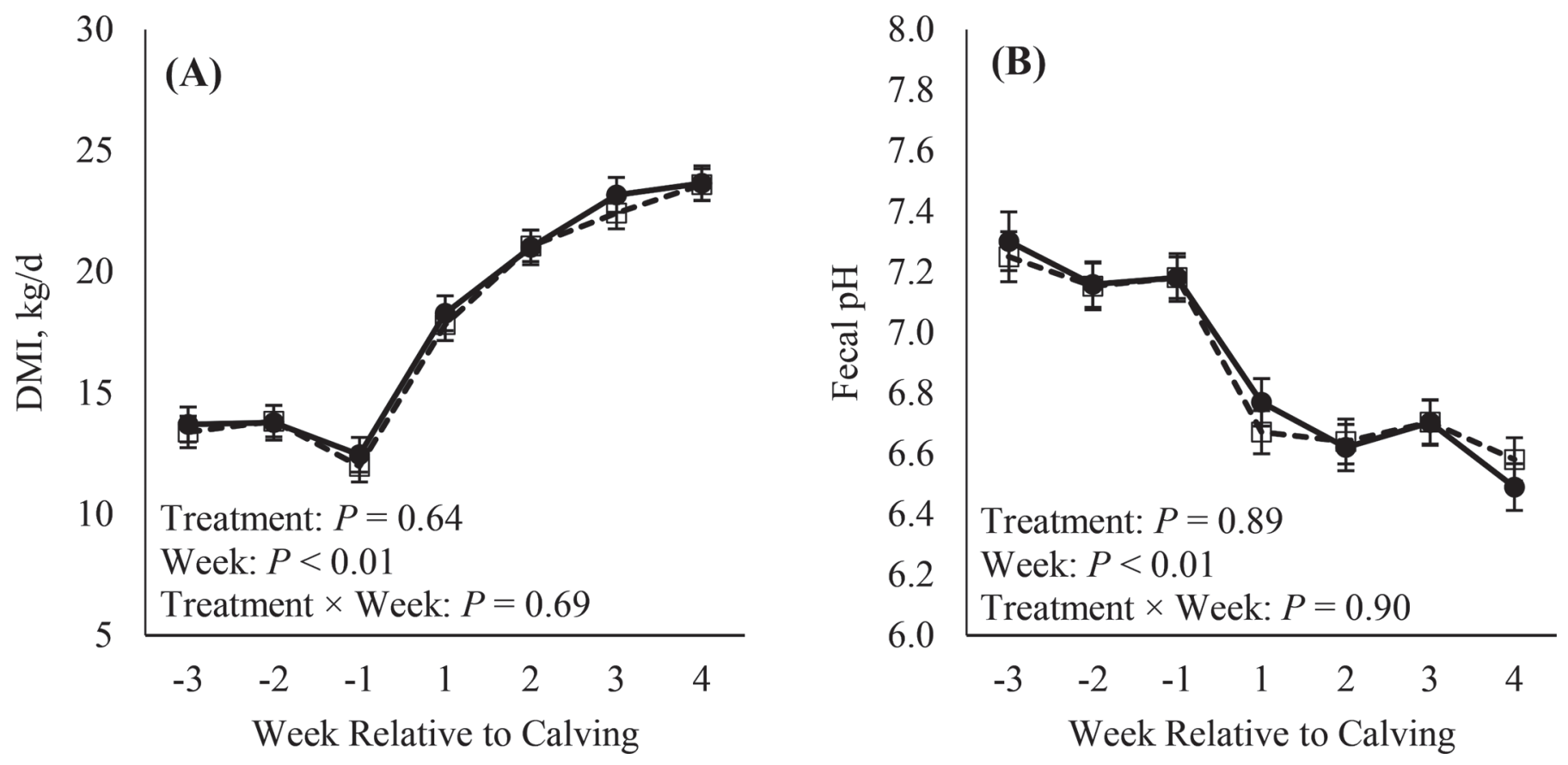

Figure 1. Effects of rumen-protected glucose on DMI (A) and fecal pH (B). Treatments: CON = control diet (shown as $\bullet$ ) and RPG $=$ rumen-protected glucose diet (shown as $\square$ ). Error bars represent SEM.

1A) with no interaction between treatment and time $(P$ $>0.69)$. However, an overall time effect was observed as DMI initially decreased $10 \%$ prepartum $(P<0.01)$, followed by a progressive increase in DMI throughout 4 wk postpartum $(P<0.01)$. Although no treatment effect was detected, fecal $\mathrm{pH}$ decreased 0.44 units from wk -1 to $1(P<0.01$; Figure $1 \mathrm{~B})$ and a further 0.18 unit decrease in fecal $\mathrm{pH}$ was observed from wk 1 to 4 postpartum $(P<0.05)$.

\section{Milk Yield and Composition}

Lactational performance is presented in Table 2; supplemental RPG had no effect on milk yield (43.1 \pm $1.2 \mathrm{~kg} / \mathrm{d} ; P>0.39)$ during the first 4 wk of lactation. Milk composition for the first 4 wk of lactation was similar for both treatments $(P \geq 0.40 ; 4.4 \pm 0.01 \%$, $3.7 \pm 0.1 \%, 4.8 \pm 0.1 \%$; for fat, protein, and lactose, respectively). Overall, supplementing RPG tended ( $P$ $=0.10)$ to increase MUN compared with CON cows (12.6 vs. $11.7 \pm 0.1 \mathrm{mg} / \mathrm{dL})$. No treatment differences were detected $(P>0.63)$ in milk SCC; however, this measurement decreased as lactation progressed for both treatment groups $(P<0.01)$. The ECM and FCM were similar between treatments $(49.2 \pm 1.4 \mathrm{~kg} / \mathrm{d}, P>0.64$ and $50.1 \pm 1.7 \mathrm{~kg} / \mathrm{d}, P>0.68$, respectively); the time effect showed that weekly ECM and FCM increased by 8.08 and $5.24 \mathrm{~kg}$, respectively, when comparing wk 1 with wk $4(P<0.01)$. Postpartum feed efficiency was not influenced by treatment $(P>0.54)$.

\section{Blood Metabolites, Hormones, and Acute Phase Proteins}

Overall, circulating glucose did not differ by treatment throughout the transition period $(60.1 \pm 1.9$ $\mathrm{mg} / \mathrm{dL} ; P>0.52$; Figure $2 \mathrm{~A}$ ); however, the distinctive and progressive hypoglycemic response associated with parturition was clear $(P \leq 0.01)$. The temporal periparturient pattern in circulating insulin mirrored $(P<0.01)$ that of glucose, but insulin concentrations tended to be higher in RPG-fed cows than in CON cows $(0.28$ vs. $0.22 \mu \mathrm{g} / \mathrm{L} ; P=0.10$; Figure $2 \mathrm{~B})$; this response was largely driven by increased concentrations postpartum $(P=0.09)$. Overall, feeding RPG decreased circulating NEFA throughout the transition period $(P<0.01$; Figure $2 \mathrm{C})$. The reduction was most pronounced postpartum, when cows consuming RPG had reduced circulating NEFA (368 vs. $508 \mu \mathrm{Eq} / \mathrm{L} ; P$ $<0.01)$. Circulating BHB was similar $(P>0.21$; Figure $2 \mathrm{D})$ for both treatments throughout the transition period but tended to be decreased ( 0.68 vs. $0.88 \mathrm{mmol} / \mathrm{L}$; $P=0.13)$ in postpartum RPG-fed cows. Concentrations of BUN did not differ $(P>0.53 ; 9.3 \pm 0.7 \mathrm{mg} /$ dL; data not shown) by treatment. Overall, circulating LBP concentrations were unaffected by treatment $(P>$ 
Table 2. Production performance of postpartum dairy cows fed a diet containing rumen-protected glucose through the transition period

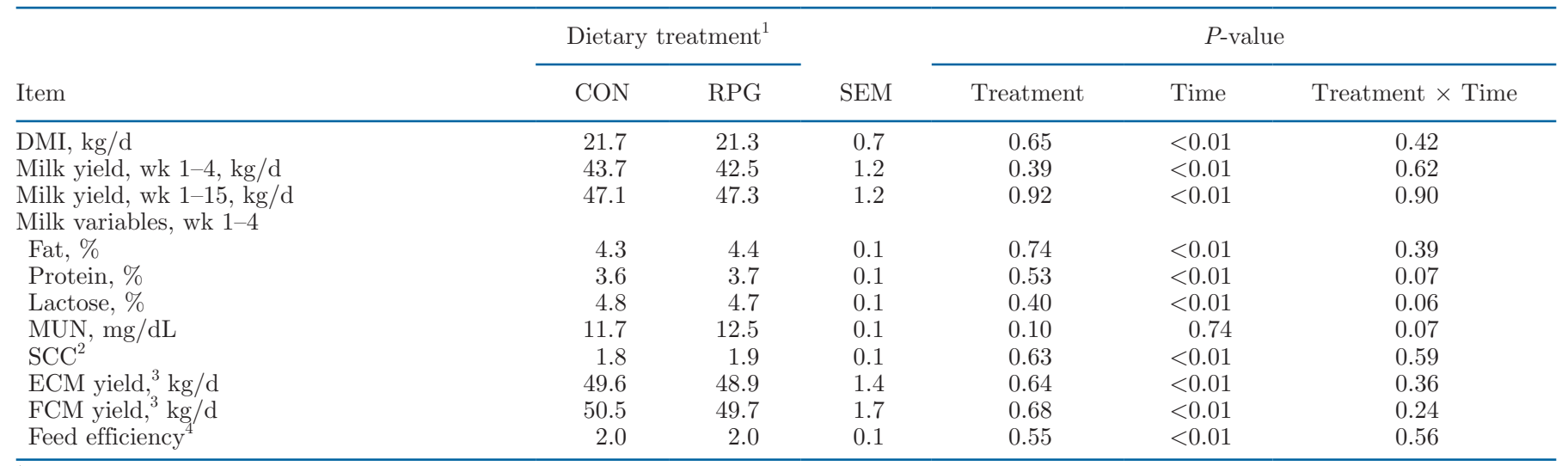

${ }^{1} \mathrm{CON}=$ control; $\mathrm{RPG}=$ rumen-protected glucose diet.

${ }^{2}$ Natural log-transformed.

${ }^{3} \mathrm{ECM}$ and FCM were calculated only for wk $1-4$.

${ }^{4}$ Efficiency of milk production (kg of milk yield/kg of DMI).

0.18; Figure 3A); however, they peaked in both treatments at 7 DIM and decreased with time $(P<0.01)$. Similarly, Hp concentrations did not differ by treatment throughout the transition period (Figure 3B). Interestingly, circulating LBP and Hp from RPG-fed cows were specifically decreased on 7 DIM relative to CON $(8.0$ vs. $5.6 \mu \mathrm{g} / \mathrm{mL}$ and 3.8 vs. $3.2 \log$ units, respectively; $P$ $\leq 0.05)$.

\section{DISCUSSION}

During early lactation, glucose availability may limit mammary synthesis of lactose and hence milk production (Overton and Waldron, 2004). Furthermore, because all cows seemingly experience some degree of inflammation after parturition (Humblet et al., 2006; Bertoni et al., 2008), and because mounting an immune response requires substantial amounts of glucose (Waldron et al., 2006; Kvidera et al., 2017), we hypothesized that early-lactation hepatic glucose output and glucose-sparing mechanisms may be inadequate to sustain both peripartum inflammation and optimum milk yield. Consequently, the goals of the experiment were to determine the effect of supplemental RPG on inflammatory biomarkers, milk yield, and bioenergetics in transitioning dairy cows.

Supplemental RPG did not negatively affect diet palatability, as evidenced by similar DMI in both groups. This contradicts previous studies that reported decreased feed intake when lactating cows were infused with glucose ruminally (Knowlton et al., 1998) or abomasally (Larsen et al., 2010). However, our DMI results are consistent with several other studies that provided glucose, either intravenously (Fisher and Elliot, 1966;
Amaral et al., 1990; Butler et al., 2015), or with postruminal starch infusion (Clark et al., 1977; Reynolds et al., 2001; Relling and Reynolds, 2008). Reasons for the aforesaid discrepancies are not clear, but it is important to note that our treatments were iso-energetic, which may have contributed to the similarities in nutrient consumption and chemostatic regulation of feed intake.

Carbohydrates are extensively fermented in the rumen, thus, minimal amounts of glucose reach the small intestine (Singleton, 1972). Though the efficiency of the small intestine to absorb glucose in ruminants remains unclear (Harmon and McLeod, 2001), it is reasonable to speculate that greater supply of glucose at the intestinal level would increase circulating insulin (assuming intestinal derived glucose would not reduce hepatic glucose output in early lactation). In this experiment, both groups of cows had similar DMI and intake of energetic precursors (starch, NFC, ether extract), thus similar energy intake. However, due to the manufacturing process of the RPG supplement, the rumen fermentability of the test diet was designed to be lower than that of the CON diet. Therefore, we expected more glucose to reach the small intestine, following the Maillard peptide complex dissociation. Post-calving RPG intake averaged about $1.3 \mathrm{~kg} / \mathrm{d}$, and based upon its soluble sugar content and reported $50 \%$ rumen protection (US Patent 8,507,025), we estimated about 315 $\mathrm{g}$ of glucose was delivered to the small intestine daily. Nevertheless, we did not observe changes in circulating glucose, but based on increased circulating insulin in RPG-fed cows (Figure 2B), it appears that the RPG increased overall glucose turnover (albeit without a change in actual glucose concentrations). However, the exact mechanism for the insulin response remains 
unclear. It may indicate that the RPG was primarily digested and absorbed intestinally as we hypothesized; however, it also plausible that the RPG was partially fermented to propionate in the rumen (not measured). This is unlikely, because the CON cows were fed a similar quantity of rumen-fermentable substrates (i.e., NFC). Regardless, increased propionate delivery to the liver would ostensibly increase hepatic gluconeogenesis rates, and the resulting enhanced glucose balance would be accompanied by hyperinsulinemia. Thus, whether or not RPG was partially metabolized in the rumen or delivered meaningful amounts of glucose post-ruminal, the altered metabolic profile (insulin, NEFA, and ketones) demonstrated that it influenced bioenergetics.

Decreased circulating insulin and insulin insensitivity of peripheral tissues after parturition play a key role
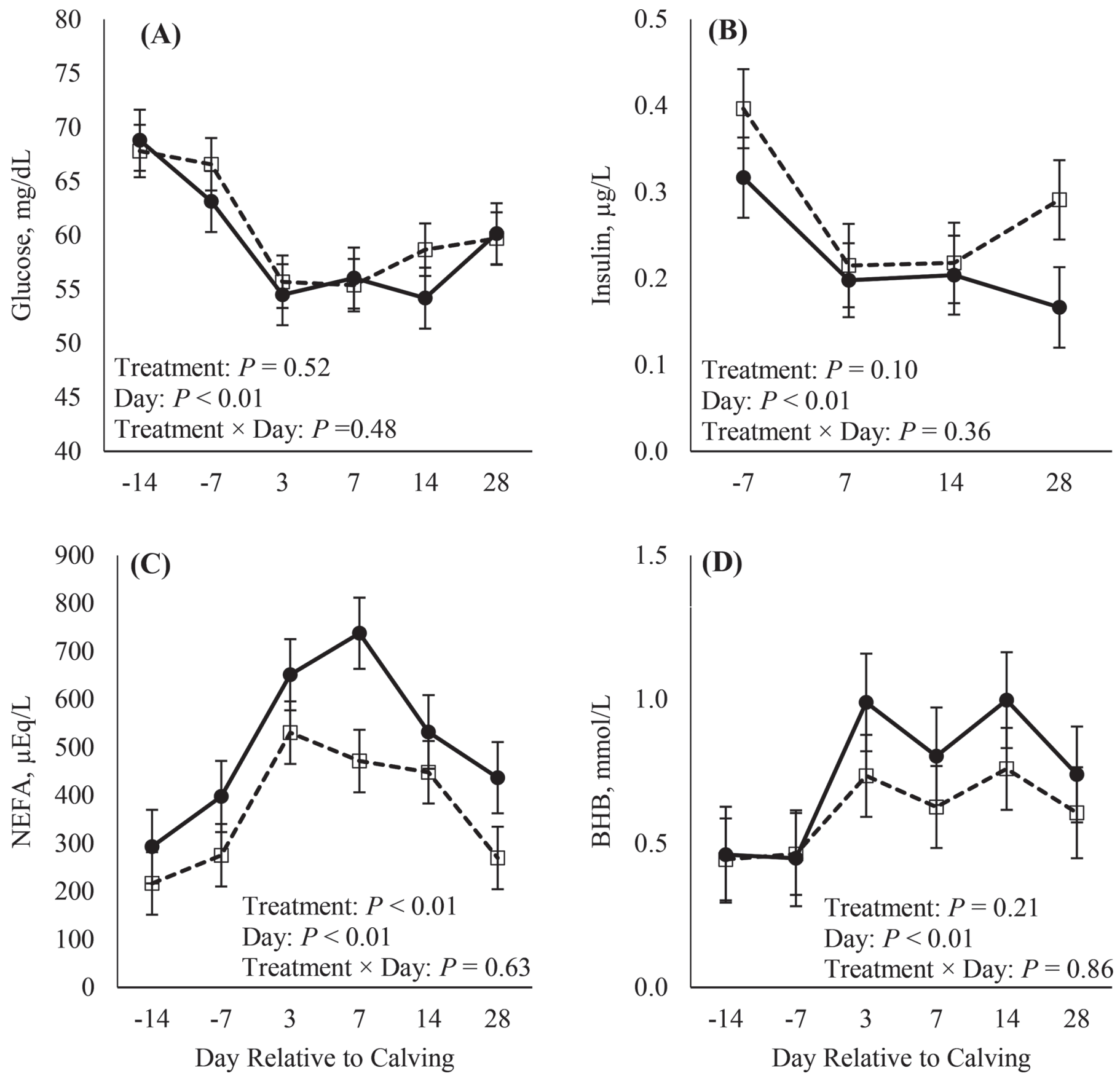

Figure 2. Effects of rumen-protected glucose on circulating glucose (A), insulin (B), nonesterified fatty acids (NEFA, C), and BHB (D). Treatments: CON = control diet (shown as - ) and RPG = rumen-protected glucose diet (shown as $\square$ ). Error bars represent SEM. 

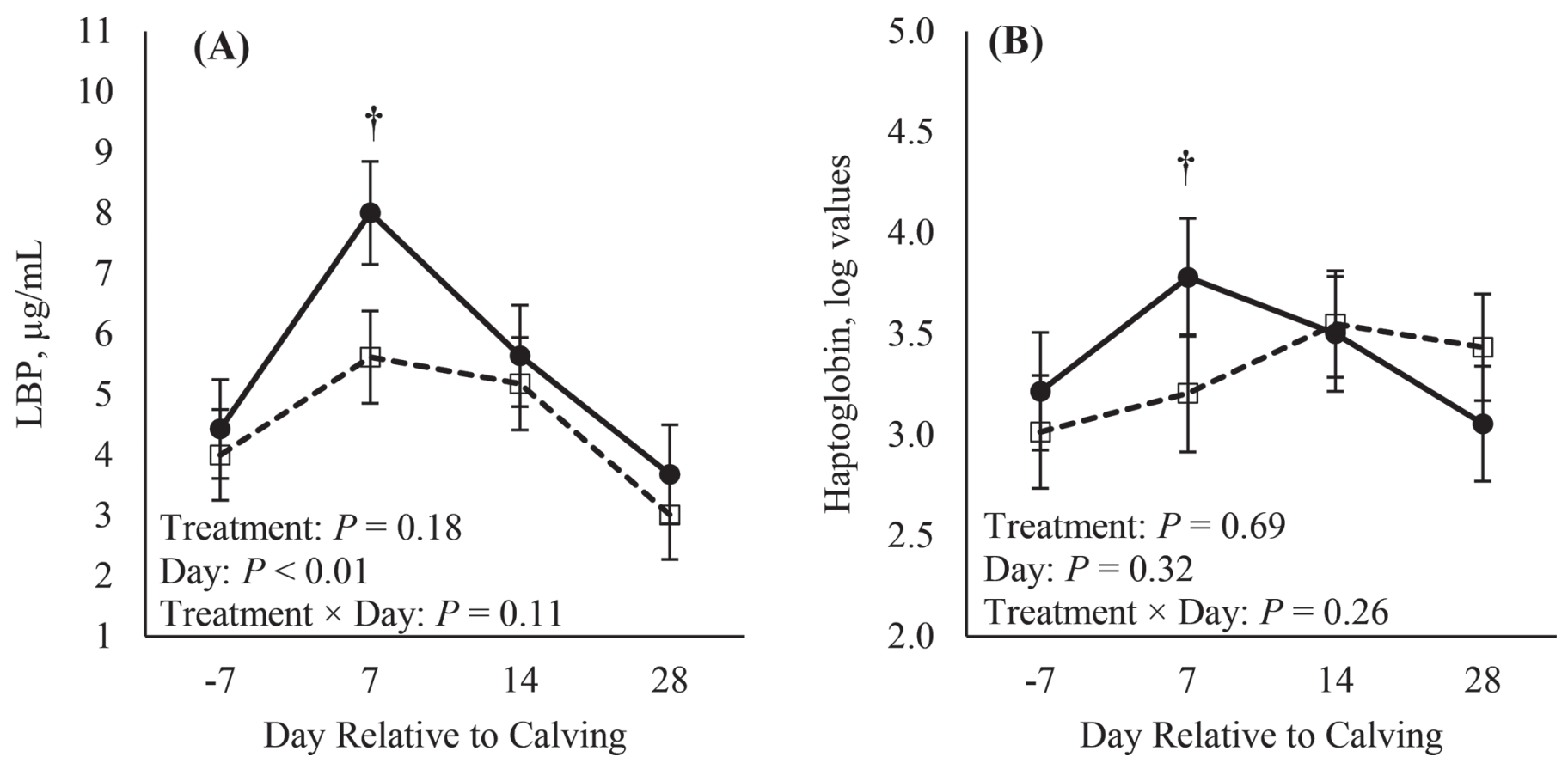

Figure 3. Effects of rumen-protected glucose on circulating lipopolysaccharide-binding protein (LBP, A) and haptoglobin (B). Treatments: $\mathrm{CON}=$ control diet (shown as $\bullet$ ) and RPG $=$ rumen-protected glucose diet (shown as $\square$ ). $\dagger$ Ad hoc analysis of specific days: $P<0.05$. Error bars represent SEM.

in the partitioning of nutrients toward the mammary gland (Vernon, 1989; Baumgard et al., 2017). Despite differences in circulating insulin, blood glucose concentrations were not altered by RPG, which is not entirely surprising, considering that glucose is homeostatically controlled (Bauman and Currie, 1980; Baumgard et al., 2017). Similarly, Amaral et al. (1990) reported that insulin tended to increase when exogenous glucose was delivered intravenously to lactating cows, with no change in circulating glucose concentration. It is likely that RPG-fed cows had an increase in glucose turnover (not measured), which was responsible for the increased insulin concentrations. Because insulin is an anabolic hormone with potent antilipolytic properties (Brockman and Laarveld, 1986), it stands to reason that this mechanism was responsible for RPG-fed cows having decreased circulating NEFA concentrations, and thus, a numerical $(P=0.13)$ decrease in BHB concentration post-parturition. Knowlton et al. (1998) reported similar results in blood bioenergetics when infusing starch into the abomasum of early-lactation cows.

Though scarce and contrasting, literature on fecal $\mathrm{pH}$ in dairy cattle has centered on measurements during a high-carbohydrate dietary challenge or abomasal infusion of carbohydrates. Results from these studies vary; for example, Gakhar et al. (2008) report that fecal pH was not altered by inducing SARA, whereas Morgante et al. (2009) reported that fecal $\mathrm{pH}$ was lower in cows with high risk of SARA. Therefore, it seems that starch and other readily digestible carbohydrates that escape rumen fermentation may represent a risk factor for hind-gut acidosis (Khafipour et al., 2009a,b). In accordance, fecal $\mathrm{pH}$ decreased upon abomasal infusion of oligofructose or starch (Reynolds et al., 2001; Bissell and Hall, 2010); however, this response is not highly repeatable across experiments (Gressley et al., 2011). Based on the lack of treatment difference in fecal $\mathrm{pH}$, our results loosely suggest that RPG was digested and absorbed before reaching the large intestine. However, it is noteworthy that fecal $\mathrm{pH}$ was markedly and consistently reduced for both treatments after calving; this observation highlights the possibility of compromised hind-gut barrier function when animals are transitioned to highly fermentable diets (Bissell and Hall, 2010).

The onset of lactation and the sustained increase in milk production imposes a strong energy demand on dairy cows during a time when nutrient consumption is inadequate and does not equilibrate with maintenance costs and energy output (Bell, 1995). We hypothesized that dietary supplementation with RPG would provide more glucose in the intestinal lumen, hence, more precursors for milk production. This response has been reported with ruminal or abomasal glucose infusion (Knowlton et al., 1998), intravenous glucose infusion (Brown and Allen, 2013), and with supplementing a "by-pass" glucose product fed during early lactation ( $\mathrm{Li}$ 
et al., 2019) and growth (Russi et al., 2019). However, milk yield was not increased when cows consumed RPG in the current study, which corroborates previous studies infusing glucose in lactating dairy cows intravenously (Fisher and Elliot, 1966; Amaral et al., 1990; Butler et al., 2015), abomasally (Clark et al., 1977; Reynolds et al., 2001; Relling and Reynolds, 2008), and duodenally (Lemosquet et al., 1997; Hurtaud et al., 1998; Reynolds et al., 2001). Reasons for this are not clear, but the mammary gland's capacity to acquire the necessary glucose appears fully adequate, even during periparturient-induced hypoglycemia. One reason for the lack of response in milk production to glucose infusions trials reported by others might be that when glucose was infused, it decreased DMI (Reynolds et al., 2001), therefore limiting the non-glucose nutrient supply to sustain increased milk production. There are a variety of different mammary glucose transporters, and some of them have a $K_{\mathrm{m}}$ (Michaelis constant) value for glucose as low as $2.4 \mathrm{mM}$ (Zhao and Keating, 2007) and glucose concentrations in the current experiment were approximately $3.0 \mathrm{mM}$. Thus, data from our experiment and others suggest that increasing milk yield immediately postpartum is not entirely dependent on increased glucose availability. It is of practical and biological relevance to elucidate reasons for discrepancies within the literature, to better characterize when and how supplemental glucose may increase milk synthesis.

Similar to previous reports (Abuajamieh et al., 2016; Kaur et al., 2019; Zincola et al., 2018), inflammatory biomarkers, namely Hp and LBP, peaked during the first weeks of lactation and then gradually decreased with time. Because these proteins are synthesized as part of immunoactivation (Uchida et al., 1993), our data agree with previous literature indicating that even seemingly healthy cows experience immunoactivation and inflammation after parturition (Humblet et al., 2006; Bertoni et al., 2008; Bradford et al., 2015). When activated, most leukocytes initiate a metabolic shift and rely primarily on aerobic glycolysis for energy production (Kelly and O'Neill, 2015), leading to a substantial increase in glucose consumption (Waldron et al., 2006; Kvidera et al., 2017). Thus, the immune system can put an additional strain on glucose homeostasis in early lactation. Interestingly, compared with controls, RPG-fed cows tended to have reduced Hp and LBP on d 7 postpartum, when the peak of inflammation occurred. Reasons for the reduced inflammatory state with no positive translation into improved milk production are not clearly known, but certainly worthy of future investigation. A different glucose-protected product for transition dairy cows decreased IL- 8 at the time of calving ( $\mathrm{Li}$ et al., 2019). Thus, it appears that the postpartum inflammatory state can be modulated nutritionally, representing a potential opportunity to affect multiple metrics of dairy profitability.

\section{CONCLUSIONS}

Although we cannot confirm that RPG was absorbed in the small intestine, based on the increased circulating insulin and decreased blood NEFA concentrations, we conclude that the RPG supplement improved bioenergetics of transition cows. Additionally, through unclear mechanisms, RPG supplementation appears to have benefited the immune system, due to decreased inflammatory response on $\mathrm{d} 7$ after calving, when the greatest immune insult appeared to have occurred. The mechanisms responsible for improving energetic status and ameliorating inflammation warrant future investigation.

\section{ACKNOWLEDGMENTS}

Results described herein were funded in part by the Norman Jacobson Endowed Professorship (Iowa State University, Ames) and Grain States Soya Inc. (West Point, NE). M. R. Knobbe and C. A. Macgregor are employees of Grain States Soya, and J. P. Russi is an employee of Rupca LLC.

\section{REFERENCES}

Abuajamieh, M., S. K. Kvidera, M. V. Sanz Fernandez, A. Nayeri, N. C. Upah, E. A. Nolan, S. M. Lei, J. M. DeFrain, H. B. Green, K. M. Schoenberg, W. E. Trout, and L. H. Baumgard. 2016. Inflammatory biomarkers are associated with ketosis in periparturient Holstein cows. Res. Vet. Sci. 109:81-85. https://doi.org/10.1016/ j.rvsc.2016.09.015.

Amaral, D. M., J. J. Veenhuizen, J. K. Drackley, M. H. Cooley, A. D. McGilliard, and J. W. Young. 1990. Metabolism of propionate, glucose, and carbon dioxide as affected by exogenous glucose in dairy cows at energy equilibrium. J. Dairy Sci. 73:1244-1254. https://doi.org/10.3168/jds.S0022-0302(90)78789-9.

Amaral-Phillips, D. M., A. D. McGilliard, G. L. Lindberg, J. J. Veenhuizen, and J. W. Young. 1993. Effects of decreased availability of glucose for dairy cows. J. Dairy Sci. 76:752-761. https://doi.org/ 10.3168/jds.S0022-0302(93)77399-3.

AOAC International. 1995. AOAC official method 972.16. Fat, lactose, protein, and solids in milk. Mid infrared spectroscopic method. Pages 23-26 in Official Methods of Analysis of AOAC International, 16th ed. Vol. 2. AOAC International, Arlington, VA.

AOAC International. 2000. AOAC official method 985.01 Metals and other elements in plants and pet foods. Inductively coupled plasma spectroscopic method. Pages 4-5 in Official Methods of Analysis of AOAC International, 17th ed. AOAC International, Arlington, VA.

AOAC International. 2006. AOAC official method 2003.05 Crude fat in feeds, cereal grains, and forages. Pages 40-42 in Official Methods of Analysis of AOAC International, 18th ed. AOAC International, Arlington, VA.

Aschenbach, J. R., G. B. Penner, F. Stumpff, and G. Gabel. 2011. Ruminant Nutrition Symposium: Role of fermentation acid absorption in the regulation of ruminal pH. J. Anim. Sci. 89:1092-1197. https://doi.org/10.2527/jas.2010-3301. 
Bauman, D. E., and W. B. Currie. 1980. Partitioning of nutrients during pregnancy and lactation: A review of mechanisms involving homeostasis and homeorhesis. J. Dairy Sci. 63:1514-1529. https:// doi.org/10.3168/jds.S0022-0302(80)83111-0.

Baumgard, L. H., R. J. Collier, and D. E. Bauman. 2017. A 100-year review: Regulation of nutrient partitioning to support lactation. J. Dairy Sci. 100:10353-10366. https://doi.org/10.3168/jds.2017 $-13242$.

Baumgard, L. H., and R. P. Rhoads Jr.. 2013. Effects of heat stress on postabsorptive metabolism and energetics. Annu. Rev. Anim. Biosci. 1:311-337. https://doi.org/10.1146/annurev-animal-031412 -103644 .

Bell, A. W. 1995. Regulation of organic nutrient metabolism during transition from late pregnancy to early lactation. J. Anim. Sci. 73:2804-2819. https://doi.org/10.2527/1995.7392804x.

Bell, A. W., and D. E. Bauman. 1997. Adaptations of glucose metabolism during pregnancy and lactation. J. Mammary Gland Biol. Neoplasia 2:265-278. https://doi.org/10.1023/A:1026336505343.

Bertoni, G., E. Trevisi, X. Han, and M. Bionaz. 2008. Effects of inflammatory conditions on liver activity in puerperium period and consequences for performance in dairy cows. J. Dairy Sci. 91:33003310 .

Bissell, H. A., and M. B. Hall. 2010. Cattle differ in ability to adapt to small intestinal digestion of starch. J. Dairy Sci. 93(E-Suppl. 1):845. (Abstr.)

Bradford, B. J., K. Yuan, J. K. Farney, L. K. Mamedova, and A. J. Carpenter. 2015. Invited review: Inflammation during the transition to lactation: New adventures with an old flame. J. Dairy Sci. 98:6631-6650. https://doi.org/10.3168/jds.2015-9683.

Branstad, E. H., C. S. Shouse, B. C. Dooley, A. D. Thomas, L. H. Baumgard, and H. A. Ramirez-Ramirez. 2017. Evaluation of the method of sample preparation for the determination of fecal $\mathrm{pH}$ in dairy cows. J. Dairy Sci. 100(Suppl. 2):99.

Brockman, R. P., and B. Laarveld. 1986. Effect of insulin on gluconeogenesis and the metabolism of lactate in sheep. Can. J. Physiol. Pharmacol. 64:1055-1059. https://doi.org/10.1139/y86-181.

Brown, W. E., and M. S. Allen. 2013. Effects of intrajugular glucose infusion on feed intake, milk yield, and metabolic responses of early postpartum cows fed diets varying in protein and starch concentration. J. Dairy Sci. 96:7132-7142. https://doi.org/10.3168/ jds.2013-6636.

Butler, S. T., S. Leane, F. Curran, S. Moore, M. Crowe, and M. Lucy. 2015. Intravenous glucose infusion in early postpartum dairy cows: Effects on plasma metabolites, milk production and interval to first ovulation. J. Dairy Sci. 98(Suppl. 2):301.

Cant, J. P., D. R. Trout, F. Qiao, and N. F. Purdie. 2002. Milk synthetic response of the bovine mammary gland to an increase in the local concentration of arterial glucose. J. Dairy Sci. 85:494-503. https://doi.org/10.3168/jds.S0022-0302(02)74100-3.

Clark, J. H., H. R. Spires, R. G. Derrig, and M. R. Bennink. 1977. Milk production, nitrogen utilization and glucose synthesis in lactating cows infused postruminally with sodium caseinate and glucose. J. Nutr. 107:631-644. https://doi.org/10.1093/jn/107.4.631.

Drackley, J. K. 1999. Biology of dairy cows during the transition period: The final frontier? J. Dairy Sci. 82:2259-2273. https://doi .org/10.3168/jds.S0022-0302(99)75474-3.

Fisher, L. J., and J. M. Elliot. 1966. Effect of intravenous infusion of propionate or glucose on bovine milk composition. J. Dairy Sci. 49:826-829. https://doi.org/10.3168/jds.S0022-0302(66)87954-7.

Gakhar, N., S. Li, D. O. Krause, E. Khafipour, K. Ominski, and J. C. Plaizier. 2008. Development of alternate markers for subacute ruminal acidosis (SARA). Page 369 in Proc. Western Canadian Dairy Seminar, Alberta, Canada. University of Alberta, Edmonton, AB, Canada.

Goering, H. K., and P. J. Van Soest. 1970. Forage Fiber Analysis. USDA Agricultural Research Service. Handbook number 379. U.S. Dept. of Agriculture. Superintendent of Documents, US Government Printing Office, Washington, DC.

Gressley, T. F., M. B. Hall, and L. E. Armentano. 2011. Ruminant Nutrition Symposium: Productivity, digestion, and health respons- es to hindgut acidosis in ruminants. J. Anim. Sci. 89:1120-1130. https://doi.org/10.2527/jas.2010-3460.

Hall, M. B. 2009. Analysis of starch, including maltooligosaccharides, in animal feeds: A comparison of methods and a recommended method for AOAC collaborative study. JAOACI 92:42-49.

Harmon, D. L., and K. R. McLeod. 2001. Glucose uptake and regulation by intestinal tissues: Implications and whole-body energetics. J. Anim. Sci. 79(E-Suppl):E59-E72. https://doi.org/10.2527/ jas2001.79E-SupplE59x.

Humblet, M. F., H. Guyot, B. Boudry, F. Mbayahi, C. Hanzen, F. Rollin, and J. M. Godeau. 2006. Relationship between haptoglobin, serum amyloid $\mathrm{A}$, and clinical status in a survey of dairy herds during a 6-month period. Vet. Clin. Pathol. 35:188-193. https:// doi.org/10.1111/j.1939-165X.2006.tb00112.x.

Hurtaud, C., H. Rulquin, and R. Verite. 1998. Effects of graded duodenal infusions of glucose on yield and composition of milk from dairy cows. Diets based on corn silage. J. Dairy Sci. 81:3239-3247. https://doi.org/10.3168/jds.S0022-0302(98)75888-6.

Kaur, M., I. Hartling, T. A. Burnett, L. B. Polsky, C. R. Donnan, H. Leclerc, D. Veira, and R. L. A. Cerri. 2019. Rumen-protected B vitamin complex supplementation during the transition period and early lactation alters endometrium mRNA expression on day 14 of gestation in lactating dairy cows. J. Dairy Sci. 102:1642-1657.

Kelly, B., and L. A. O'Neill. 2015. Metabolic reprogramming in macrophages and dendritic cells in innate immunity. Cell Res. 25:771784. https://doi.org/10.1038/cr.2015.68.

Khafipour, E., D. Krause, and J. Plaizier. 2009. A grain-based subacute ruminal acidosis challenge causes translocation of lipopolysaccharide and triggers inflammation. J. Dairy Sci. 92:1060-1070. https://doi.org/10.3168/jds.2008-1389.

Khafipour, E., D. O. Krause, and J. C. Plaizier. 2009a. A grain-based subacute ruminal acidosis challenge causes translocation of lipopolysaccharide and triggers inflammation. J. Dairy Sci. 92:10601070. https://doi.org/10.3168/jds.2008-1389.

Khafipour, E., D. O. Krause, and J. C. Plaizier. 2009b. Alfalfa pelletinduced subacute ruminal acidosis in dairy cows increases bacterial endotoxin in the rumen without causing inflammation. J. Dairy Sci. 92:1712-1724. https://doi.org/10.3168/jds.2008-1656.

Knowlton, K. F., T. E. Dawson, B. P. Glenn, G. B. Huntington, and R. A. Erdman. 1998. Glucose metabolism and milk yield of cows infused abomasally or ruminally with starch. J. Dairy Sci. 81:32483258. https://doi.org/10.3168/jds.S0022-0302(98)75889-8.

Kostyukovsky, V., and M. Marounek. 1995. Maillard reaction products as a substrate in in vitro rumen fermentation. Anim. Feed Sci. Tech. 55:201-206. https://doi.org/10.1016/0377-8401(95)00804-V.

Kronfeld, D. S. 1982. Major metabolic determinants of milk volume, mammary efficiency, and spontaneous ketosis in dairy cows. J. Dairy Sci. 65:2204-2212. https://doi.org/10.3168/jds.S0022 -0302(82)82483-1.

Kvidera, S. K., E. A. Horst, M. Abuajamieh, E. J. Mayorga, M. V. Sanz Fernandez, and L. H. Baumgard. 2017. Glucose requirements of an activated immune system in lactating Holstein cows. J. Dairy Sci. 100:2360-2374. https://doi.org/10.3168/jds.2016-12001.

Larsen, M., A. E. Relling, C. K. Reynolds, and N. B. Kristensen. 2010. Effect of abomasal glucose infusion on plasma concentrations of gut peptides in periparturient dairy cows. J. Dairy Sci. 93:5729-5736. https://doi.org/10.3168/jds.2010-3258.

Lemosquet, S., E. Delamaire, H. Lapierre, J. W. Blum, and J. L. Peyraud. 2009. Effects of glucose, propionic acid, and nonessential amino acids on glucose metabolism and milk yield in Holstein dairy cows. J. Dairy Sci. 92:3244-3257. https://doi.org/10.3168/ jds.2008-1610.

Lemosquet, S., J. Rideau, H. Rulquin, P. Faverdin, J. Simon, and R. Verite. 1997. Effects of a duodenal glucose infusion on the relationship between plasma concentrations of glucose and insulin in dairy cows. J. Dairy Sci. 80:2854-2865. https://doi.org/10.3168/ jds.S0022-0302(97)76250-7.

Li, X. P., Z. L. Tan, J. Z. Jiao, D. L. Long, C. S. Zhou, K. L. Yi, C. H. Liu, J. H. Kang, M. Wang, F. H. Duan, S. X. Tang, Z. X. He, and X. F. Han. 2019. Supplementation with fat-coated rumen-protect- 
ed glucose during the transition period enhances milk production and influences blood biochemical parameters of liver function and inflammation in dairy cows. Anim. Feed Sci. Technol. 252:92-102. https://doi.org/10.1016/j.anifeedsci.2019.04.010.

Morgante, M., M. Gianesella, S. Casella, L. Ravarotto, C. Stelletta, and E. Giudice. 2009. Blood gas analyses, ruminal and blood pH, urine and faecal $\mathrm{pH}$ in dairy cows during subacute ruminal acidosis. Comp. Clin. Pathol. 18:229-232. https://doi.org/10.1007/ s00580-008-0793-4.

National Research Council. 2001. Nutrient Requirements of Dairy Cattle. 7th rev. ed. Natl. Acad. Press, Washington, DC.

Neville, M. C., J. C. Allen, and C. Watters. 1983. The mechanisms of milk secretion. Pages 49-92 in Lactation: Physiology, Nutrition, and Breast-Feeding. M. C. Neville and M. R. Neifert, ed. Plenum, New York, NY.

Overton, T. R., and M. R. Waldron. 2004. Nutritional management of transition dairy cows: Strategies to optimize metabolic health. J. Dairy Sci. 87:E105-E119. https://doi.org/10.3168/jds.S0022 -0302(04)70066-1.

Relling, A. E., and C. K. Reynolds. 2008. Abomasal infusion of casein, starch and soybean oil differentially affect plasma concentrations of gut peptides and feed intake in lactating dairy cows. Domest. Anim. Endocrinol. 35:35-45. https://doi.org/10.1016/j.domaniend .2008 .01 .005 .

Reynolds, C. K., S. B. Cammell, D. J. Humphries, D. E. Beever, J. D. Sutton, and J. R. Newbold. 2001. Effects of postrumen starch infusion on milk production and energy metabolism in dairy cows. J. Dairy Sci. 84:2250-2259. https://doi.org/10.3168/jds.S0022 -0302(01)74672-3.

Russi, J. P., N. DiLorenzo, and A. E. Relling. 2019. Effects of rumen-protected carbohydrate supplementation on performance and blood metabolites in feedlot finishing steers during heat stress. Transl. Anim. Sci. 3:513-521. https://doi.org/10.1093/tas/txy122.
Singleton, A. G. 1972. The control of fermentation of carbohydrate. Proc. Nutr. Soc. 31:147-149. https://doi.org/10.1079/ PNS19720029.

Uchida, E., N. Katoh, and K. Takahashi. 1993. Appearance of haptoglobin in serum from cows at parturition. J. Vet. Med. Sci. 55:893894. https://doi.org/10.1292/jvms.55.893.

Van Soest, P. J. 1994. Pages 174-176 in Nutritional Ecology of the Ruminant, 2nd ed. Cornell University Press, Ithaca, NY.

Van Soest, P. J., J. B. Robertson, and B. A. Lewis. 1991. Methods for dietary fiber, neutral detergent fiber, and nonstarch polysaccharides in relation to animal nutrition. J. Dairy Sci. 74:3583-3597.

Vernon, R. G. 1989. Endocrine control of metabolic adaptation during lactation. Proc. Nutr. Soc. 48:23-32. https://doi.org/10.1079/ PNS19890006.

Waldron, M. R., A. E. Kulick, A. W. Bell, and T. R. Overton. 2006. Acute experimental mastitis is not causal toward the development of energy-related metabolic disorders in early postpartum dairy cows. J. Dairy Sci. 89:596-610. https://doi.org/10.3168/jds.S0022 -0302(06)72123-3.

Wildman, E. E., G. M. Jones, P. E. Wagner, R. L. Bowman, H. F. Troutt Jr., and T. N. Lesch. 1982. A dairy cow body condition scoring system and relationship to selected production characteristics. J. Dairy Sci. 65:495-501.

Zhao, F. Q., and A. F. Keating. 2007. Expression and regulation of glucose transporters in the bovine mammary gland. J. Dairy Sci. 90(E. Suppl.):E76-E86. https://doi.org/10.3168/jds.2006-470.

Zinicola, M., H. Korzec, A. G. V. Teixeira, E. K. Ganda, L. Bringhenti, A. C. C. H. Tomazi, R. O. Gilbert, and R. C. Bicalho. 2018. Effects of pegbovigrastim administration on periparturient diseases, milk production, and reproductive performance of Holstein cows. J. Dairy Sci. 101:11199-11217. https://doi.org/10.3168/jds .2018-14869. 